\title{
A high cell wall negative charge is necessary for the growth of the alkaliphile Bacillus lentus C-125 at elevated $\mathrm{pH}$
}

\author{
Rikizo Aono, ${ }^{1}$ Masahiro Ito, ${ }^{1}$ Keith N. Joblin ${ }^{2}$ and Koki Horikoshi ${ }^{1}$
}

Author for correspondence: Rikizo Aono. Fax: +81 459245819.

\footnotetext{
1 Department of

Bioengineering, Faculty of Bioscience and

Biotechnology, Tokyo Institute of Technology, Nagatsuta 4259,

Yokohama 226, Japan

2 Grasslands Research Centre, AgResearch Private Bag 11008, Palmerston North, New Zealand
}

\begin{abstract}
The structural components in cell walls of three mutants of a facultative alkaliphile, Bacillus lentus C-125, defective in certain cell-wall components were characterized in detail. The cell walls of the wild-type C-125 were thick and increased in thickness when grown at high pH. Electron microscopy showed that triple layers developed when the bacteria were grown in an alkaline environment. In contrast, cell walls of teichuronopeptide (TUP)defective mutants consisted of a single layer. For both the wild-type and mutants, the cell-wall concentrations of the acidic structural polymers teichuronic acid and TUP increased with respect to peptidoglycan as culture pH increased. For all four strains, the anion content of their cell walls was the greatest at high pH. The cell-wall density of the negatively charged compounds (uronic acids plus L-glutamic acid) was calculated as about 3 and 9 equivalents (I cell wall region) $)^{-1}$ for $\mathrm{C}-125$ cells grown at pH 7 and 10, respectively. At high pH, the specific growth rates of the two TUP-defective mutants were much lower than those of the wild-type. It is concluded that increased levels of acidic polymers in the cell walls of alkaliphilic bacteria may be a necessary adaptation for growth at elevated pH.
\end{abstract}

Keywords: alkaliphile, Bacillus lentus, cell wall, negative charge

\section{INTRODUCTION}

The facultative alkaliphile Bacillus lentus $\mathrm{C}-125$ grows between $\mathrm{pH} 6.8$ and $10 \cdot 8$. This organism used to be called Bacillus sp. C-125 (Aono \& Horikoshi, 1983); however, recently this organism was shown to be related to $B$. lentus (Aono, 1995). It has been reported that a $\Delta \psi$-dependent $\mathrm{Na}^{+} / \mathrm{H}^{+}$antiporter on the cell membrane helps to maintain the intracellular $\mathrm{pH}$ around neutrality (Kitada et al., 1994). The bacterial cell wall also appears to be important for the development and maintenance of alkaliphily. Protoplasts prepared from strain C-125 are unstable at alkaline $\mathrm{pH}$ (Aono et al., 1992) and regenerate at neutral $\mathrm{pH}$ but not at alkaline $\mathrm{pH}$ (Aono et al., 1993). The cell wall of alkaliphiles possibly acts as an obstacle to the high extracellular concentrations of hydroxide ions and as a reservoir of hydrogen ions generated intracellularly by respiration.

The cell walls of $B$. lentus $\mathrm{C}-125$ contain peptidoglycan,

Abbreviations: DAP, diaminopimelic acid; PGU, polyglucuronic acid TCA, trichloroacetic acid; TUA, teichuronic acid; TUP, teichuronopeptide. teichuronic acid (TUA) and teichuronopeptide (TUP). The peptidoglycan is an A1 $\gamma$ type that is identical to that in the cell walls of the neutrophilic Bacillus subtilis (Aono et al., 1984). The TUA consists of galacturonic acid, glucuronic acid and N-acetyl-D-2-amino-2,6dideoxygalactose (fucosamine) in a molar ratio of $1: 1: 1$ (Aono \& Uramoto, 1986). The TUP is a polymer in which polyglutamic acid binds covalently to polyglucuronic acid (PGU) and has a 1:4.5 molar ratio of glucuronic acid to Lglutamic acid (Aono, 1985, 1987, 1989). The quantities of acidic polymers in the cell walls of strain $\mathrm{C}-125$ increase when cells are grown at alkaline $\mathrm{pH}$ (Aono \& Horikoshi, 1983; Aono, 1985). Mutants defective in the acidic polymers grow poorly on an alkaline solid medium (Aono \& Ohtani, 1990; Ito et al., 1994).

These studies suggested that the acidic polymers in the cell walls might be important for bacterial growth in an alkaline environment. However, this conclusion was drawn from experiments with cells from cultures grown at initial $\mathrm{pH}$ values of 7.0 or 10.0 but lacking $\mathrm{pH}$ control during growth. Moreover, there have been few detailed measurements of the composition of the cell walls of alkaliphiles and little is known about the effects of culture 
$\mathrm{pH}$ on cell-wall morphology. We have examined cellwall-defective mutants grown under $\mathrm{pH}$ control. In this paper, we describe in detail the $\mathrm{pH}$-dependent alteration of the chemical composition of cell walls of the C-125 wild-type and the mutants, the $\mathrm{pH}$-dependent specific growth rates of the strains, and the ultrastructure of cell walls of the strains grown at several $\mathrm{pH}$ values.

\section{METHODS}

Bacterial strains. The strains used in this study are listed in Table 1. All mutant strains are derivatives of an alkaliphilic strain of B. lentus C-125 (FERM 7344; Fermentation Research Institute, Agency of Industrial Science and Technology, Ministry of International Trade and Industry, Tsukuba, Japan). Strain C-125-11, a mutant lacking TUA, was obtained by treating a threonine-requiring and streptomycin-resistant derivative of $\mathrm{C}-125$ with ethylmethanesulphonate (Aono \& Ohtani, 1990). Strain C-125-90 obtained from C-125-11 lacks TUA and the polyglutamic acid moiety of TUP. Strain C-125F19 (methionine-requiring and nalidixic-acid resistant) was constructed by protoplast fusion between $\mathrm{C}-125-90$ and the wild-type strain. 'The cell walls of C-125-F19 contain TUA and lack the polyglutamic-acid chain of TUP (Aono et al., 1994; Ito et al., 1994).

Media and growth conditions. The bacteria were aerobically grown at $37^{\circ} \mathrm{C}$ in a medium consisting of $(1 \text { deionized water })^{-1}$ : $\mathrm{K}_{2} \mathrm{HPO}_{4}, 13.7 \mathrm{~g} ; \mathrm{KH}_{2} \mathrm{PO}_{4}, 5.9 \mathrm{~g}$; citric acid, $0.34 \mathrm{~g}$; $\mathrm{MgSO}_{4} \cdot 7 \mathrm{H}_{2} \mathrm{O}, 0.05 \mathrm{~g}$; glucose, $5 \mathrm{~g}$; peptone, $5 \mathrm{~g}$; yeast extract, $1 \mathrm{~g} ; \mathrm{Na}_{2} \mathrm{CO}_{3}, 10.6 \mathrm{~g}$. The $\mathrm{pH}$ of this medium was about 10 (Aono, 1985).

When it was necessary to keep the $\mathrm{pH}$ constant during growth, bacteria were grown in 31 batches in a $10 \mathrm{l}$ jar equipped with a $\mathrm{pH}$-stat apparatus. The required $\mathrm{pH}$ values were initially established in the medium described above by using the following buffers and then maintained by the automatic addition of $1 \mathrm{M} \mathrm{HCl}$ or $1 \mathrm{M} \mathrm{NaOH}$ during cultivation. The initial $\mathrm{pH}$ values were established by adjusting the medium with the following buffers: $\mathrm{pH} 6.5-7 \cdot 0,0.1 \mathrm{M} \quad \mathrm{K}_{2} \mathrm{HPO}_{4} / 0.2 \mathrm{M}$ $\mathrm{NaCl} / \mathrm{HCl} ;$ pH 8.0, $0.1 \mathrm{M} \mathrm{K}_{2} \mathrm{HPO}_{4} / 0.14 \mathrm{M} \mathrm{NaCl} / 0.03 \mathrm{M}$ $\mathrm{Na}_{2} \mathrm{CO}_{3} ;$ pH 9.0, $0.1 \mathrm{M} \mathrm{K}_{2} \mathrm{HPO}_{4} / 0.1 \mathrm{M} \quad \mathrm{NaHCO}_{3} / 0.05 \mathrm{M}$ $\mathrm{Na}_{2} \mathrm{CO}_{3}$; pH 10.0-11.0, 0.2 M KCl/0.05 M Na $\mathrm{CO}_{3} / \mathrm{NaOH}$. Air was bubbled into the medium at a flow rate of $4.51 \mathrm{~min}^{-1}$. The culture was stirred at 350 r.p.m.

Preparation of the cell walls. Cells were harvested by centrifugation $\left(8000 \mathrm{~g}, 4^{\circ} \mathrm{C}, 10 \mathrm{~min}\right)$ of a portion of the culture containing cells at the late-exponential phase of growth. The cells (wet wt 7-10 g) were immediately suspended in $300 \mathrm{ml}$ hot $2 \%(\mathrm{w} / \mathrm{v})$ SDS solution containing $0.1 \mathrm{M} \mathrm{NaCl}$, and autolytic enzymes (Aono \& Sanada, 1994) were inactivated by incubation of the suspension at $80^{\circ} \mathrm{C}$ for $30 \mathrm{~min}$. Cells were collected by centrifugation $\left(8000 \mathrm{~g}, 20^{\circ} \mathrm{C}, 15 \mathrm{~min}\right)$, suspended in three times the volume of $0 \cdot 1 \mathrm{M} \mathrm{NaCl}$ containing $0 \cdot 1 \% \mathrm{NaN}_{3}$, and disrupted with a sonic oscillator ( $200 \mathrm{~W}$, room temperature, $20 \mathrm{~min})$. The sonicated lysate was centrifuged $\left(8000 \mathrm{~g}, 20^{\circ} \mathrm{C}, 15 \mathrm{~min}\right)$ to remove unbroken cells, and an equal volume of $4 \%(\mathrm{w} / \mathrm{v})$ SDS solution was added to the broken-cell suspension. Mixtures were incubated at $80^{\circ} \mathrm{C}$ for $30 \mathrm{~min}$. Cell walls were sedimented by centrifugation $\left(20000 \mathrm{~g}, 20^{\circ} \mathrm{C}, 30 \mathrm{~min}\right)$ and then washed four times with $0 \cdot 1 \mathrm{M} \mathrm{NaCl}$ containing $0 \cdot 1 \% \mathrm{NaN}_{3}$. Washed cell walls were resuspended in $50 \mathrm{mM}$ Tris $/ \mathrm{HCl}(\mathrm{pH} \mathrm{7.9)}$ containing $10 \mathrm{mM} \mathrm{CaCl}_{2}$, and digested with trypsin $\left(0.5 \mathrm{mg} \mathrm{ml}^{-1}\right)$ at $37^{\circ} \mathrm{C}$ overnight. Cell walls were subsequently washed several times with $10 \mathrm{mM}$ EDTA/ $\mathrm{NaOH}\left(\mathrm{pH} \mathrm{7 \cdot 3)}, 0 \cdot 1 \mathrm{M} \mathrm{NaCl} / 0 \cdot 1 \% \mathrm{NaN}_{3}\right.$, and deionized water (Aono \& Horikoshi, 1983).
Isolation of non-peptidoglycan components from cell walls. Cell walls were extracted with warm $5 \%(\mathrm{w} / \mathrm{v})$ trichloroacetic acid (TCA) three times as described previously by Aono (1985). TCA extracts were exhaustively dialysed against running water in a dialysis tube with an $M_{\mathrm{r}}$ cut-off of 3500 (Spectropore). The dialysate was mixed with an equal volume of $0.1 \mathrm{M}$ acetic acid/ $\mathrm{NaOH}$ buffer ( $\mathrm{pH} 5 \cdot 0$ ) and loaded on to a column of DE$52(1.5 \times 50 \mathrm{~cm}$; Whatman) which had been equilibrated with $50 \mathrm{mM}$ acetic acid/ $\mathrm{NaOH}$ buffer $(\mathrm{pH} 5 \cdot 0)$. The column was washed with $60 \mathrm{ml}$ of the buffer and eluted with $60 \mathrm{ml}$ of the same buffer containing $0.2 \mathrm{M} \mathrm{NaCl}$, followed by a linear gradient elution from 0.2 to $0.6 \mathrm{M} \mathrm{NaCl}$ in the buffer $(200 \mathrm{ml})$ at a flow rate of $80 \mathrm{ml} \mathrm{h}^{-1}$. The column was finally eluted with buffer containing $0.6 \mathrm{M} \mathrm{NaCl}$. Fractions $(3 \mathrm{ml})$ were assayed for uronic acids, amino sugars and L-glutamic acid. The fractions containing these compounds were pooled and dialysed against deionized water $\left(M_{r}\right.$ cut-off 3500$)$.

A portion of the samples was concentrated to about $1 \mathrm{ml}$ in a rotary evaporator at $40^{\circ} \mathrm{C}$. The residual solution was applied to a column of Toyopearl HW55S $(1.5 \times 97 \mathrm{~cm}$; Toyo Soda) (sold under the name of Fractogel TSK-HW55S in some areas) which had been equilibrated with $0.2 \mathrm{M} \mathrm{NaCl}$. The column was eluted with $0.2 \mathrm{M} \mathrm{NaCl}$. Fractions $(1.3 \mathrm{ml})$ containing uronic acids were dialysed against deionized water.

$\boldsymbol{M}_{\mathrm{r}}$ values. $M_{\mathrm{r}}$ values of samples were estimated by gel chromatography on two columns of Shodex WS 802.5F (Showa Denko) connected in series to an HPLC apparatus. The columns were eluted with $0 \cdot 1 \mathrm{M} \mathrm{NaH} \mathrm{PO}_{4} / \mathrm{NaOH}$ buffer $(\mathrm{pH} 7 \cdot 2$ ) at a flow rate of $1.0 \mathrm{ml} \mathrm{h}^{-1}$. The elution pattern was monitored by measuring refractive index with a differential refractive index detector (RID-300; Nippon Bunko). $M_{\mathrm{r}}$ standards of authentic pullulans (Shodex Standard P-82; Showa Denko) were used to calibrate the gel chromatography.

TLC. Ascending Avicel cellulose thin-layer chromatograms were run using the following solvents: (A) ethyl acetate/pyridine/ water/acetic acid (5:5:3:1, by vol.) at room temperature; (B) phenol $/ 1 \%$ aqueous ammonia $(5: 2, \mathrm{v} / \mathrm{v})$ at $43^{\circ} \mathrm{C}$. Separated components were located with alkaline silver nitrate (Trevelyan et al., 1950) or ninhydrin (Stepka, 1957) spray. Glucosamine$\mathrm{HCl}$, glutamic acid, glucuronic acid and galacturonic acid (Wako Pure Chemical Industries) were used as the authentic standards.

Paper electrophoresis. Samples were spotted in the middle of Whatman no. 1 filter paper, $40 \mathrm{~cm}$ in length, and electrophoresed in $10 \%(\mathrm{v} / \mathrm{v})$ acetic acid/pyridine buffer $(\mathrm{pH} \mathrm{2.5})$ at $12.5 \mathrm{~V} \mathrm{~cm}^{-1}$ for $2 \mathrm{~h}$. Separated compounds were located with the alkaline silver nitrate or ninhydrin spray.

\section{Analyses}

(i) Uronic acids. Uronic acids were determined by the carbazole reagent method (Davidson, 1966) using glucuronic acid as a reference standard.

(ii) Amino compounds. Samples were hydrolysed in $4 \mathrm{M} \mathrm{HCl}$ for $16 \mathrm{~h}$ at $100^{\circ} \mathrm{C}$ in sealed tubes. Amino sugars were assayed by the Elson-Morgan reaction (Wheat, 1966) using glucosamine or fucosamine as a reference standard. Authentic fucosamine was prepared from the walls of $B$. lentus $\mathrm{C}-125$ (Aono \& Uramoto, 1986). L-Glutamic acid content was determined by using Lglutamic acid dehydrogenase and diaphorase (Beutler \& Michal, 1974). The hydrolysates were also analysed with an amino acid analyser to determine diaminopimelic acid (DAP) and fucosamine.

Electron microscopy. Growing cells were fixed by the addition of an equal volume of the fresh medium containing $8 \%(v / v)$ glutaraldehyde to the culture. The mixture was kept at room 
Table 1. Bacterial strains used

Abbreviations: $\mathrm{Thr}^{-}$, threonine requirement; $\mathrm{Met}^{-}$, methionine requirement; $\mathrm{Str}^{\mathrm{r}}$, streptomycin resistance; $\mathrm{Nal}^{\mathrm{r}}$, nalidixic-acid resistance; $\mathrm{TUA}^{-}$, loss of $\mathrm{TUA}^{-}$;UP-Glu${ }^{-}$, loss of poly(glutamic acid) chain in TUP.

\begin{tabular}{|c|c|c|}
\hline Strain & Phenotype & Reference \\
\hline$C-125$ & Wild-type & Aono \& Horikoshi (1983) \\
\hline C-125-11 & $\mathrm{Thr}^{-} \mathrm{Str}^{\mathrm{r}} \mathrm{TUA}^{-}$ & Aono \& Ohtani (1990) \\
\hline C-125-90 & $\mathrm{Thr}^{-} \mathrm{Str}^{\mathrm{r}} \mathrm{TUA}^{-} \mathrm{TUP}^{-G^{-}}$ & Aono \& Ohtani (1990) \\
\hline C-125-F19 & Met $^{-}$Str $^{r}$ Nal ${ }^{r}$ TUP-Glu- & Ito et al. (1994) \\
\hline
\end{tabular}

temperature for $1-2 \mathrm{~h}$ and then at $4{ }^{\circ} \mathrm{C}$ overnight. Samples were sedimented by centrifugation $\left(1000 \mathrm{~g}, 15 \mathrm{~min}, 20^{\circ} \mathrm{C}\right)$ and resuspended in $0.1 \mathrm{M}$ sodium cacodylate buffer $(\mathrm{pH} \mathrm{7.2)}$ containing $4 \%(\mathrm{v} / \mathrm{v})$ glutaraldehyde for several days. The fixed

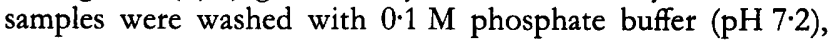
post-fixed with $\mathrm{OsO}_{4}$ at $4{ }^{\circ} \mathrm{C}$, dehydrated and embedded in epoxy resin. Sections stained with uranyl acetate and costained with lead citrate were observed in a Philips 201C electron microscope.

\section{RESULTS AND DISCUSSION}

\section{Extraction of the non-peptidoglycan components from the cell-wall-defective mutants}

Cell walls from C-125 and C-125-11 were prepared from cells grown in 21 alkaline medium to an $\mathrm{OD}_{660}$ of 2 . Cell walls from C-125-90 and C-125-F19 were prepared from cells grown in $2.5 \mathrm{l}$ of the same medium to an $\mathrm{OD}_{660}$ of $0 \cdot 7-0.8$. The cell-wall preparations contained the following amounts of uronic acids $\left(\mu \mathrm{mol} \mathrm{l}^{-1} \mathrm{OD}_{660}{ }^{-1}\right)$ : $\mathrm{C}$ -
125, 53; C-125-11, 23; C-125-F19, 67; C-125-90, 55. The insoluble material remaining after repeated TCA extraction represents only $2-4 \%$ of the original uronic acids and consists mainly of peptidoglycans (Aono et al., 1984). The TCA extracts contained little peptidoglycan.

After dialysis and anionic ion-exchange column chromatography, $90-95 \%$ of the solubilized uronic acid residues were recovered. High recoveries of uronic acids were also found for TCA extracts of cell-wall preparations from organisms grown in neutral medium (results not shown). These results indicate that the major source of uronic acid residues is the high- $M_{\mathbf{r}}$ polymers in the cell-wall preparations.

\section{Characterization of cell-wall components of the cell- wall-defective mutants grown at pH 10}

TUA and TUP found in the cell walls of wild-type strain C-125 can be separated from each other by DEAEcellulose column chromatography (Aono, 1985). The

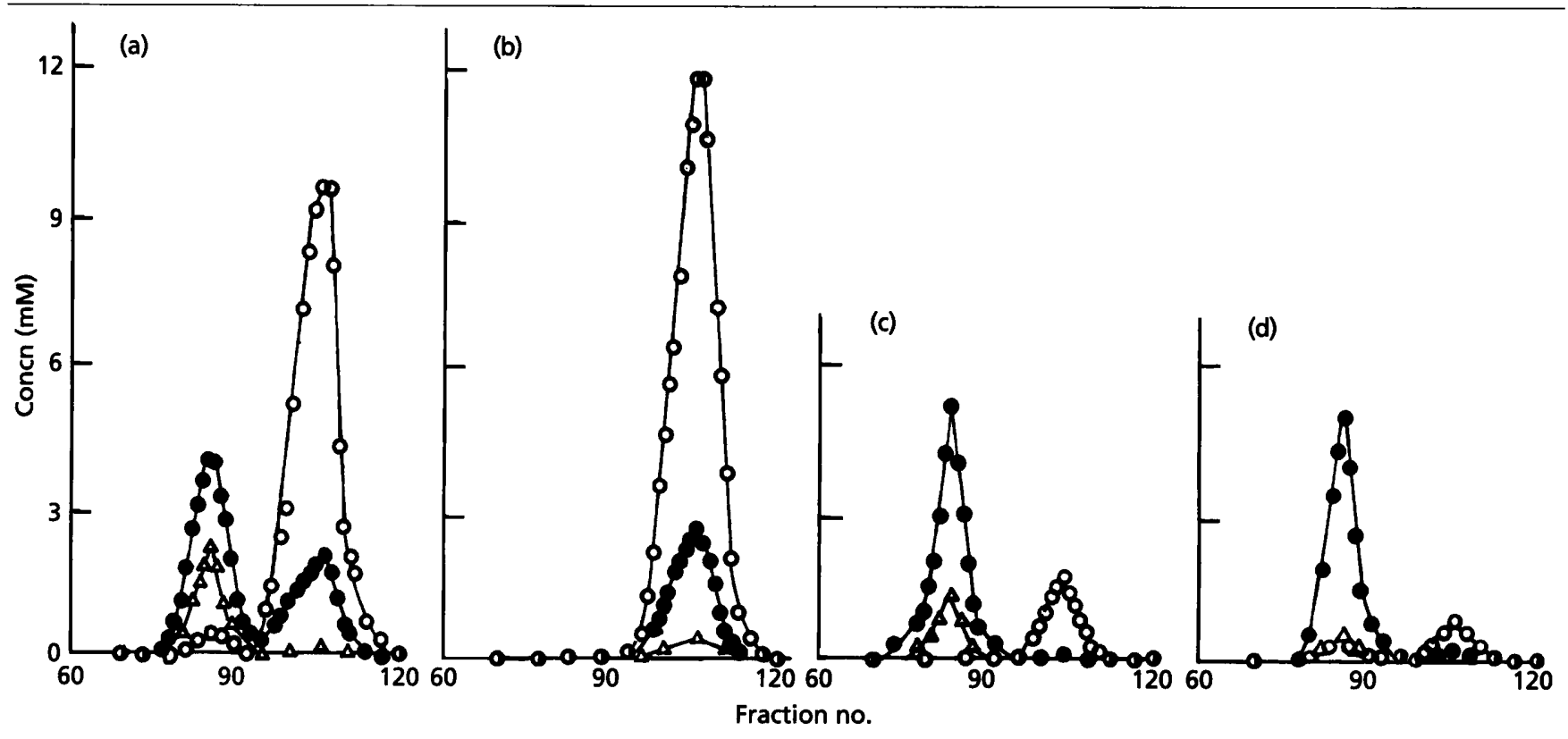

Fig. 1. DEAE-cellulose column chromatography of the non-dialysable TCA extract of cell walls. Cell walls were prepared from cells of C-125 (a), C-125-11 (b), C-125-F19 (c) or C-125-90 (d) grown in alkaline medium and extracted. The extracts were chromatographed as described in Methods. Fractions ( $3 \mathrm{ml})$ were collected and assayed for uronic acids (O), l-glutamic acid $(O)$ and amino sugars $(\triangle)$. Each concentration is shown in $\mathrm{mM}$. 
Table 2. Characteristics of non-peptidoglycan acidic polymers in the bacterial cell walls

Cell-wall polymers extracted with TCA were purified by DEAEcellulose chromatography. The $M_{\mathrm{r}}$ of each polymer was estimated by gel chromatography. The constituents of each polymer were identified by Avicel cellulose TLC and paper electrophoresis after hydrolysis. Abbreviations: PGU, polyglucuronic acid derived as a mutant-type TUP deprived of a polyglutamic acid chain; GlcU, glucuronic acid; GalU, galacturonic acid; L-Glu, L-glutamic acid.

\begin{tabular}{|lcrl|}
\hline Strain & Component & $\boldsymbol{M}_{\mathbf{r}}$ & Constituents \\
\hline C-125 & TUA & 44000 & GlcU GalU FucN \\
& TUP & 21000 & GlcU L-Glu \\
C-125-11 & TUP & 21000 & GlcU L-Glu \\
C-125-90 & PGU & 7300 & GlcU \\
& TUP & 21000 & GlcU L-Glu \\
C-125-F19 & TUA & 38000 & GlcU GalU FucN \\
& PGU & 7200 & GlcU \\
& TUP & 21000 & GlcU L-Glu \\
\hline
\end{tabular}

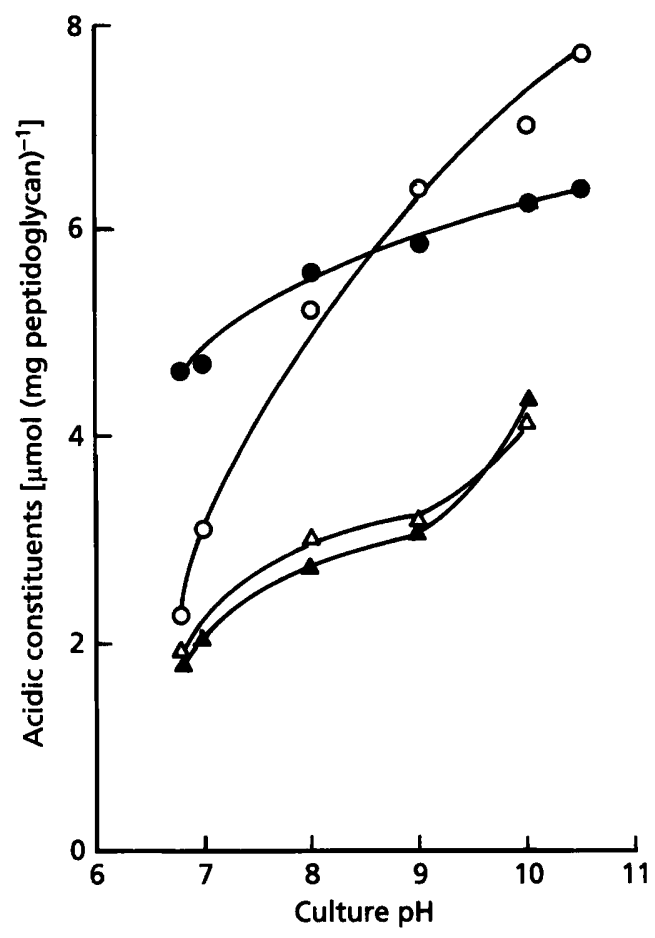

Fig. 2. Culture-pH dependence of the acidic constituents in cell walls. Strains C-125 (O), C-125-11 (O), C-125-F19 $(\triangle)$ and C-12590 (A) were grown at several $\mathrm{pH}$ values. The acidic and DAP levels in the cell walls were determined as described in Methods. The total amounts of acidic constituents (uronic acids and L-glutamic acid) are represented (mg peptidoglycan) ${ }^{-1}$.

TUA, composed of galacturonic acid, glucuronic acid and fucosamine, eluted with $0.33 \mathrm{M} \mathrm{NaCl}$. The TUP, which has glucuronic acid and glutamic acid as constituents, eluted with $0.45 \mathrm{M} \mathrm{NaCl}$ (Fig. 1a; Table 2).
In contrast, chromatography of the TCA extract of cell walls of C-125-11 yielded only one peak (Fig. 1b). This peak eluted with $0.45 \mathrm{M} \mathrm{NaCl}$ and consisted mainly of glucuronic acid and glutamic acid (Table 2), showing that the peak was derived from TUP. This proves that the cell walls of C-125-11 do not contain TUA and do not contain any equivalent polymer to replace the missing TUA. Previously, it has been assumed that the mutant C-125-11 lacks TUA because fucosamine was not detected in a hydrolysate of the cell walls of the strain (Aono \& Ohtani, 1990).

TCA extracts from the mutant C-125-90 contained two polymers (Fig. 1d). One polymer eluted with $0.32 \mathrm{M} \mathrm{NaCl}$ and consisted of only glucuronic acid and a small amount of galactosamine residues (Table 2). This compound was PGU with an $M_{\mathrm{r}}$ of 7100 and corresponds to the PGU moiety of TUP, which was previously prepared by hydrazinolysis of TUP (Aono, 1989). The $M_{\mathrm{r}}$ was greater than the value of 4800 determined for the hydrazinolysis product. It is possible that the PGU moiety had been partially decomposed during the hydrazinolysis in the previous study. Another cell-wall polymer of C-125-90 (Fig. 1d) eluted with $0.45 \mathrm{M} \mathrm{NaCl}$ and is TUP. The chemical composition and $M_{\mathrm{r}}$ are similar to those of the TUP prepared from the wild-type strain (Table 2). The TUP levels varied considerably between different cultures of C-125-90. C-125-90 readily produces a revertant similar to $\mathrm{C}-125-11$ at high $\mathrm{pH}$. This revertant had TUP but not TUA or PGU (results not shown). It is believed that the TUP levels found here are from the revertant rather than from C-125-90. An alternative explanation is that C-12590 is a mutant leaky in TUP synthesis. Recently we have cloned a DNA fragment from the wild-type C- 125 that complements the defect in TUP synthesis in the mutants C-125-90 and C-125-F19 (results not shown). Future analysis of this DNA fragment may reveal characteristics of the mutation and the gene products involved in TUP synthesis.

DEAE-cellulose chromatography of the TCA extracts from C-125-F19 showed that this mutant contained TUA, TUP and PGU (Fig. 1c). The highly acidic fraction that eluted with $0.4 \mathrm{M} \mathrm{NaCl}$ consisted of a TUP identical to that extracted from $\mathrm{C}-125$, as found in $\mathrm{C}-125-90$. The polymers present in the low-acidic-component fraction that eluted with $0.3 \mathrm{M} \mathrm{NaCl}$ were further fractionated by gel chromatography on Toyopearl HW55S to yield two substances (results not shown). The higher $M_{\mathrm{r}}$ polymer was TUA of a chemical composition identical to that of wild-type TUA. The lower $M_{\mathrm{r}}$ polymer was PGU (a mutant-type TUP consisting only of PGU chains) identical with that extracted from C-125-90 cell walls (Table 2). C-125-F19 has been constructed by cell fusion of protoplasts from C-125-90 and the wild-type strain (Aono et al., 1994; Ito $e t$ al., 1994), and its cell-wall polymers reflect the parentage of the fusion product.

The results described above for the cell-wall polymers are for cells grown at $\mathrm{pH} 10$. Similar results were obtained for cells grown at $\mathrm{pH} 7$, but the amounts of acidic polymers were much reduced in this case (see later). 


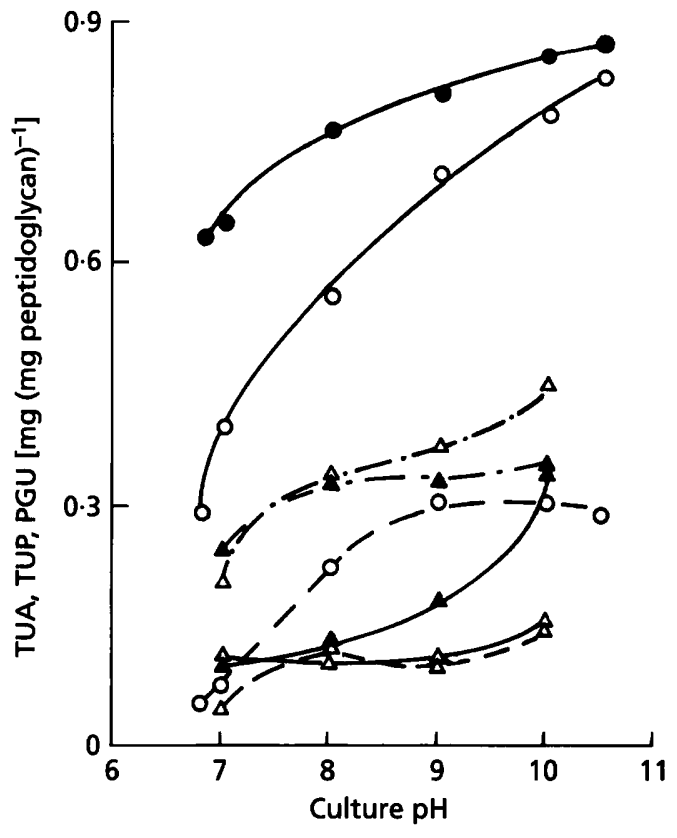

Fig. 3. Culture-pH dependence of acidic polymers in cell walls. Contents of TUA (broken line), TUP (solid line), and PGU (broken line and dot) in the cell walls of strains C-125 (O), C125-11 (O), C-125-F19 $(\triangle)$ and C-125-90 ( $\Delta$ ) were calculated from the chemical compositions of the cell-wall preparations (Table 3). The polymer levels are presented (mg peptidoglycan) ${ }^{-1}$.

\section{Culture-pH-dependent accumulation of the acidic constituents in the cell walls}

The chemical composition of cell walls from the alkaliphilic B. lentus $\mathrm{C}-125$ grown at $\mathrm{pH} 7$ or 10 has been reported previously by Aono \& Horikoshi (1983) and Aono (1985). Uronic acids are the major constituents of the acidic non-peptidoglycan polymers TUA, TUP and PGU. Fucosamine, L-glutamic acid and DAP are unique constituents of TUP, TUA and peptidoglycan, respectively. In the present study, the constituents of cell walls prepared from mutants defective in cell-wall components grown at six $\mathrm{pH}$ values were measured in order to evaluate the influence of culture $\mathrm{pH}$ on the acidic polymer concentrations (Figs 2 and 3; Table 3). The $\mathrm{pH}$ values were kept constant during the growth. The amount of peptidoglycan was calculated by multiplying the measured DAP content by $884\left(\mu \mathrm{g} \mu \mathrm{mol}^{-1}\right)$. This factor has been experimentally determined on the basis of the chemical composition of peptidoglycan prepared from strain C-125 (Aono et al., 1984). In the cell walls, fucosamine is $N$ acetylated (Aono, 1985). Galacturonic acid, glucuronic acid and glutamic acid residues occur as monovalent acidic residues in the polymers. Therefore, the anionic charge on cell walls can be approximately estimated from the total amount of acidic compounds.

The results listing the levels of L-glutamic acid, uronic acids and fucosamine relative to DAP in the cell walls are given in Table 3, together with the total anionic charge concentrations. The results show that the cell walls of the
Table 3. Culture-pH dependence of the nonpeptidoglycan components of cell walls

The cell walls were prepared from bacteria grown at the constant $\mathrm{pH}$ indicated and assayed for constituents of TUA, TUP and peptidoglycan. The L-glutamic acid (L-Glu), uronic acids (UA) and fucosamine $(\mathrm{FucN})$ contents relative to the DAP content are shown. ND, Not detected.

\begin{tabular}{|c|c|c|c|c|c|}
\hline \multirow[t]{2}{*}{ Strain } & \multirow[t]{2}{*}{$\begin{array}{l}\text { Culture } \\
\text { pH }\end{array}$} & \multicolumn{4}{|c|}{$\begin{array}{l}\text { Amounts relative to DAP } \\
\qquad\left(\mu \mathrm{mol} \mu \mathrm{mol}^{-1}\right)\end{array}$} \\
\hline & & L-Glu & UA & FucN & $\begin{array}{c}\text { Total } \\
\text { anionic } \\
\text { compounds }\end{array}$ \\
\hline \multirow[t]{6}{*}{ C-125 } & 6.8 & 1.50 & 0.51 & 0.08 & $2 \cdot 0$ \\
\hline & $7 \cdot 0$ & $2 \cdot 10$ & 0.69 & $0 \cdot 12$ & $2 \cdot 8$ \\
\hline & $8 \cdot 0$ & $2 \cdot 90$ & $1 \cdot 70$ & 0.36 & $4 \cdot 6$ \\
\hline & $9 \cdot 0$ & $3 \cdot 70$ & 1.90 & 0.49 & $5 \cdot 6$ \\
\hline & $10 \cdot 0$ & $4 \cdot 10$ & $2 \cdot 10$ & 0.49 & $6 \cdot 2$ \\
\hline & $10 \cdot 5$ & $4 \cdot 40$ & $2 \cdot 40$ & $0 \cdot 46$ & $6 \cdot 8$ \\
\hline \multirow[t]{6}{*}{ C-125-11 } & $6 \cdot 8$ & $3 \cdot 40$ & 0.74 & ND & $4 \cdot 1$ \\
\hline & $7 \cdot 0$ & $3 \cdot 40$ & 0.79 & ND & $4 \cdot 2$ \\
\hline & $8 \cdot 0$ & $4 \cdot 10$ & 0.90 & ND & $5 \cdot 0$ \\
\hline & $9 \cdot 0$ & $4 \cdot 30$ & 0.91 & ND & $5 \cdot 2$ \\
\hline & $10 \cdot 0$ & $4 \cdot 50$ & $1 \cdot 00$ & ND & $5 \cdot 5$ \\
\hline & $10 \cdot 5$ & $4 \cdot 60$ & $1 \cdot 10$ & ND & $5 \cdot 7$ \\
\hline \multirow[t]{5}{*}{ C-125-F19 } & 6.8 & 0.47 & $1 \cdot 20$ & $0 \cdot 19$ & $1 \cdot 7$ \\
\hline & $7 \cdot 0$ & 0.53 & $1 \cdot 30$ & 0.07 & $1 \cdot 8$ \\
\hline & $8 \cdot 0$ & $0 \cdot 50$ & $2 \cdot 20$ & $0 \cdot 19$ & $2 \cdot 7$ \\
\hline & $9 \cdot 0$ & 0.53 & $2 \cdot 30$ & $0 \cdot 15$ & $2 \cdot 8$ \\
\hline & $10 \cdot 0$ & $0 \cdot 80$ & $2 \cdot 90$ & $0 \cdot 23$ & $3 \cdot 7$ \\
\hline \multirow[t]{5}{*}{ C- $125-90$} & 6.8 & 0.46 & $1 \cdot 10$ & ND & 1.6 \\
\hline & $7 \cdot 0$ & 0.51 & $1 \cdot 30$ & ND & $1 \cdot 8$ \\
\hline & $8 \cdot 0$ & 0.65 & $1 \cdot 80$ & ND & $2 \cdot 4$ \\
\hline & $9 \cdot 0$ & 0.92 & $1 \cdot 80$ & ND & $2 \cdot 7$ \\
\hline & $10 \cdot 5$ & $1 \cdot 75$ & $2 \cdot 10$ & ND & $3 \cdot 8$ \\
\hline
\end{tabular}

four alkaliphilic strains grown in high alkaline environments were highly anionic compared to the cell walls from the bacteria grown in neutral environments. In the case of C-125, L-glutamic acid was the predominant acidic compound and this increased almost threefold with respect to DAP when the culture $\mathrm{pH}$ increased from 6.8 to $10 \cdot 5$. The relative concentrations of uronic acids increased over fourfold. The total acidic constituents in the cell walls increased from $2.0 \mu \mathrm{mol}(\mu \mathrm{mol} \mathrm{DAP})^{-1}$ in cells grown at $\mathrm{pH} 6.8$ to $6.8 \mu \mathrm{mol}(\mu \mathrm{mol} \mathrm{DAP})^{-1}$ in cells grown at $\mathrm{pH} 10 \cdot 5$.

Similarly, the amounts of acidic cell-wall compounds increased with culture $\mathrm{pH}$ for each of the mutants, although the amounts of anionic compounds in the three mutants increased less with increasing culture $\mathrm{pH}$ than was found for the wild-type. C-125-11 had highly anionic cell walls irrespective of the culture $\mathrm{pH}$ due to overproduction of TUP (Fig. 3; Table 3). This mutant had $4.1 \mu \mathrm{mol}$ acidic compounds (mg peptidoglycan) ${ }^{-1}$ even when grown at $\mathrm{pH} 6 \cdot 8$. The amount of acidic compounds 
of strains C-125-F19 and C-125-90 was $1 \cdot 6-1 \cdot 7 \mu \mathrm{mol}(\mathrm{mg}$ peptidoglycan $)^{-1}$ at $\mathrm{pH} 6.8$ and $3.7-3.9 \mu \mathrm{mol}$ (mg peptidoglycan $)^{-1}$ at $\mathrm{pH} 10$.

To assess the effects of culture $\mathrm{pH}$ on the amounts of TUA and TUP in the cell walls, the TUA and TUP levels were calculated by multiplying the fucosamine and L-glutamic acid contents by 539 and $168\left(\mu \mathrm{g} \mu \mathrm{mol}^{-1}\right)$, respectively. These factors were determined from the chemical composition of the free-acid forms of TUA and TUP (Aono, $1985,1989)$. PGU, which appeared only in the cell walls of C-125-90 and -F19, was composed mainly of glucuronic acid (Table 2). Therefore, the PGU content was estimated by multiplying the excess uronic-acid content by 176 $\left(\mu \mathrm{g} \mu \mathrm{mol}^{-1}\right)$. This excess uronic acid was the residue not involved in formation of TUA or TUP. The excess uronic-acid residue content was calculated by subtraction of the uronic-acid content in TUA (twice that of the fucosamine content) and subtraction of the uronic-acid content of TUP ( $22 \%$ that of the L-glutamic acid content) from the total content of uronic acids in the cell walls.

The estimated TUA, TUP and PGU content per unit of peptidoglycan in the cell walls of the four strains and the changes in their concentration with culture $\mathrm{pH}$ are presented in Fig. 3. The acidic polymers probably exist as the sodium or potassium salts in cells growing at high $\mathrm{pH}$, but the results in Fig. 3 were calculated as the free-acid forms for convenience.

In $\mathrm{C}-125$ cell walls, the TUA concentration increased in a linear-pH-dependent manner between $\mathrm{pH} 6.8$ and 9.0 and then remained almost constant at higher $\mathrm{pH}$ (Fig. 3). The concentration of TUA was only $50 \mu \mathrm{g}$ (mg peptidoglycan $)^{-1}$ at $\mathrm{pH} 6.8$ but increased to $300 \mu \mathrm{g}$ (mg peptidoglycan $)^{-1}$ at $\mathrm{pH} 9 \cdot 0$. In contrast, the TUP concentration increased over the whole $\mathrm{pH}$ range tested with a nearlinear increase from $\mathrm{pH} 8$ to 10.5 . At pH 6.8 and 10.5 , the TUP concentration was 280 and $830 \mu \mathrm{g}$ (mg peptidoglycan $)^{-1}$, respectively. These results show that culture $\mathrm{pH}$ affects the synthesis of both TUA and TUP, and suggest that the synthesis of the two polymers is not linked.

For C-125-11, the acidic polymer in the cell walls is only TUP (Fig. 1b). At pH 6.8 and 10.5, the respective TUP concentrations were 640 and $870 \mu \mathrm{g}$ (mg peptidoglycan $)^{-1}$. At $\mathrm{pH}$ values below 8 , the TUP concentration was far greater than that in the parent strain (C-125). TUP synthesis possibly increased in response to low concentration of TUA. An enhanced TUP content might complement biological defects brought about by the lack of TUA, although little is known about the biological functions of TUP and TUA at present.

The mutant C-125-90 prepared by mutating strain C-12511 also did not contain TUA. Cultures of C-125-90 grown at high $\mathrm{pH}$ often contained C-125-11-type revertant cells. It was difficult to interpret results from cultures of this mutant because of the presence of wild-type TUP (a complex of PGU and polyglutamic acid), which probably arose from the revertants. The cell-wall preparation contained 90 and $330 \mu \mathrm{g}$ wild-type TUP (mg peptidoglycan $)^{-1}$ when the organism was grown at $\mathrm{pH} 6.8$ or
$10 \cdot 0$, respectively. These values were equivalent to $0 \cdot 004$ and $0.016 \mu \mathrm{mol}$ (mg peptidoglycan $)^{-1}$. The cell walls of $\mathrm{C}-$ 125-90 contained PGU, a mutant type of TUP lacking the polyglutamic acid chain (Fig. 1d). The PGU content was $200 \mu \mathrm{g}(0.028 \mu \mathrm{mol})(\mathrm{mg} \text { peptidoglycan })^{-1}$ at $\mathrm{pH} 6.8$ and $350 \mu \mathrm{g}(0.048 \mu \mathrm{mol})(\mathrm{mg} \text { peptidoglycan })^{-1}$ at $\mathrm{pH} 10.0$, which compared with respective values of 0.030 and $0.041 \mu \mathrm{mol}$ TUP (mg peptidoglycan) ${ }^{-1}$ found in the cell walls of C-125-11 grown under these culture conditions.

For strain C-125-F19, wild-type TUP was found in the cell-wall preparation (Fig. 1c) but the amount was less than that in C-125-90 at pH 9 or 10 (Fig. 3). This probably indicates that $\mathrm{C}-125-\mathrm{F} 19$ was more stable than $\mathrm{C}-125-90$ at alkaline $\mathrm{pH}$. This stability might be due to restoration of TUA and to a consequent increase in negative charges in the cell walls of strain C-125-F19. At $\mathrm{pH} \mathrm{10.0} \mathrm{the} \mathrm{amount}$ of TUA was $120 \mu \mathrm{g}$ (mg peptidoglycan $)^{-1}$, which is about a half of that of $\mathrm{C}-125$ grown at the same $\mathrm{pH}$. The cell-wall preparation contained 90 and $150 \mu \mathrm{g} \quad(0.004$ and $0.007 \mu \mathrm{mol}$, respectively) of wild-type TUP (mg peptidoglycan $)^{-1}$ when $\mathrm{C}-125-\mathrm{F} 19$ was grown at $\mathrm{pH} 6.8$ and $10 \cdot 0$, respectively. Cell walls also contained 150 and $450 \mu \mathrm{g}$ PGU (mg peptidoglycan) ${ }^{-1}$ at $\mathrm{pH} 6.8$ and 10.5, respectively. This corresponds to 0.021 and $0.062 \mu \mathrm{mol}$ PGU (mg peptidoglycan) $)^{-1}$, respectively.

In summary, synthesis of the acidic polymers TUA and TUP increased markedly when the facultative alkaliphilic strain C-125 was grown at alkaline $\mathrm{pH}$. TUA and TUP give anionic charges to the cell walls, and changes in the content of these polymers will alter the negative-charge density in the cell-wall matrix (Fig. 2). We previously compared the chemical composition of cell walls prepared from a neutrophilic strain of $B$. subtilis and 10 alkaliphilic strains of Bacillus spp. (Aono \& Horikoshi, 1983). Teichoic acid containing phosphor was a major acidic constituent in the cell wall of $B$. subtilis. The phosphor content was $1.8 \mu \mathrm{mol}(\mathrm{mg} \text { cell wall })^{-1}$ and $3.6 \mu \mathrm{mol}(\mu \mathrm{mol}$ DAP $)^{-1}$. Anionic charges expected in the cell wall of $B$. subtilis due to the phosphor can be supposed to be similar to those of $B$. lentus $\mathrm{C}-125$ grown at $\mathrm{pH} \mathrm{7-8} \mathrm{(Table} 3$ ). The cell wall of $\mathrm{C}-125$ grown at $\mathrm{pH} 10.5$ was enriched in about twice the amount of acidic compounds as that in B. subtilis.

\section{pH-dependent growth of mutants defective in cell- wall components}

A series of growth studies was carried out in liquid medium under $\mathrm{pH}$ control to determine the growth rates of the cell-wall-defective mutants and the wild-type. At alkaline $\mathrm{pH}$, the three mutants grew with lower growth rates than the parent strain (Fig. 4). C-125 did not grow at $\mathrm{pH} 6.5$ or 11.0 when cultured under $\mathrm{pH}$ control, but grew between $\mathrm{pH} 6.8$ and $10 \cdot 8$ with optimum growth at $\mathrm{pH} 9$. The specific growth rates were $0.77,1.33$ and $0.34 \mathrm{~h}^{-1}$ at pH 6.8, 9.0 and $10 \cdot 8$, respectively. None of the mutant strains grew below $\mathrm{pH} 6.5$.

Mutant strain C-125-11 grew between $\mathrm{pH} 6.8$ and $10 \cdot 7$ with optimum growth at $\mathrm{pH} 8$. This mutant did not grow at $\mathrm{pH} 10 \cdot 8$. The growth rate at $\mathrm{pH} 10.0$ and 10.5 was $85 \%$ 


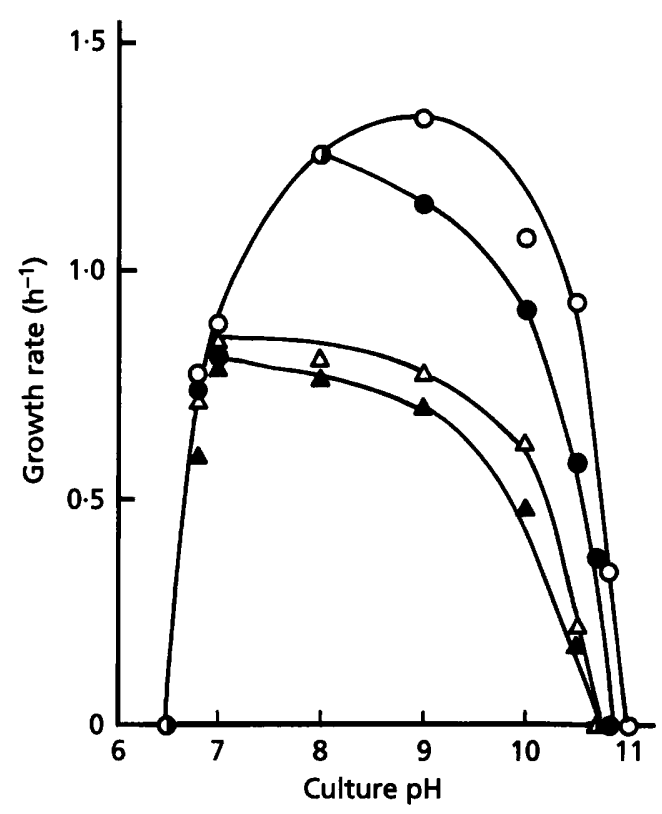

Fig. 4. Effect of culture $\mathrm{pH}$ on growth of alkaliphilic $B$. lentus and its cell-wall-defective derivatives. Strains C-125 (O), C-125$11(O), C-125-F 19(\triangle)$ and C-125-90 (A) were grown at several constant $\mathrm{pH}$ values. Specific growth rates were calculated from generation times derived from increases in turbidity $\left(O D_{600}\right.$ was measured).

and $60 \%$ of that of $\mathrm{C}-125$, respectively. Mutants C-125F19 and $\mathrm{C}-125-90$ grew between $\mathrm{pH} 6.8$ and 10.5, and both showed growth optima at $\mathrm{pH} 7$, with growth rates $90 \%$ that of $\mathrm{C}-125$. These mutants did not grow at $\mathrm{pH} 10.7$ and had growth rates only $20 \%$ of that of $\mathrm{C}-125$ at $\mathrm{pH} 10.5$ (Fig. 4).

At neutral $\mathrm{pH}$, the growth rates of mutants and the wildtype were similar despite the differences in cell-wall constituents. The growth rates of the mutants at $\mathrm{pH} 7$ were almost equal to that of $\mathrm{C}-125$. Above $\mathrm{pH} 8$, the growth rates of all the mutants continually reduced as $\mathrm{pH}$ increased, and the growth rates remained in the order C125-11 > C-125-F19 > C125-90. At their $\mathrm{pH}$ optima, the growth rates of the mutants were very similar to that of wild-type C-125 growing at the same $\mathrm{pH}$. It appears that the alkaliphilic nature of the mutant strains has been reduced by the changes to the cell-wall constituents. However, these changes were not sufficient for the mutants to grow below the lower-pH limit for growth of $\mathrm{C}-125$ or to grow more rapidly at neutral $\mathrm{pH}$ than $\mathrm{C}-125$. Interestingly, the mutant with the most similar growth rates to $\mathrm{C}-125$ is $\mathrm{C}-125-11$, and this mutant has completely lost the TUA component of its cell walls. From the growth rate curves in Fig. 4, it can be seen that C-125-11 resembles $\mathrm{C}-125$, whereas $\mathrm{C}-125-\mathrm{F} 19$ resembles $\mathrm{C}-125-90$. This resemblance reflects the similarities in the concentrations of anionic compounds in the cell walls of the four strains (Fig. 2; Table 3) and leads us to conclude again that TUA and TUP function on the cell surface of alkaliphilic bacteria as an obstacle to high concentrations of $\mathrm{OH}^{-}$.

\section{Ultrastructure of cell walls of alkaliphilic B. lentus C- 125 and its mutants}

The cell-wall features of the four strains in the exponential phase of growth were monitored by electron microscopy. B. lentus C-125 is Gram-positive and has a relatively thick cell-wall layer (Fig. 5a). The thickness and other morphological features of the cell walls varied with culture $\mathrm{pH}$, although this phenomenon was observed on the micrographs showing dehydrated walls but not hydrated walls surrounding the growing cells. The dehydrated cell walls are likely to be thinner than the in vivo hydrated cell walls.

The cell walls of the organism grown at $\mathrm{pH} 10$ (A-wall) were thicker than those of the organism grown at $\mathrm{pH} 7 \cdot 2$ (N-wall), as shown in Table 4. The A-wall was $22 \mathrm{~nm}$ in thickness, which was similar to that of $B$. subtilis cell walls (Mera et al., 1992). Triple layers consisting of electrondense, electron-opaque and electron-dense lamellae were well developed in the A-wall (Fig. 5b). This multiple lamellae structure was poorly developed in the $\mathrm{N}$-wall and the electron-opaque layer between the two electron-dense layers was evident in only a few of the cells grown at $\mathrm{pH} 7$ (Fig. 5c). The $\mathrm{N}$-wall of most $\mathrm{C}-125$ cells appeared as an electron-dense monolayer of $18 \mathrm{~nm}$ thickness. All the multiple layers disappeared upon digestion of the peptidoglycan with egg-white lysozyme (Aono et al., 1994) but were not affected by trypsin (results not shown).

For mutant C-125-11, triple layers were also present in the A-walls (19 $\mathrm{nm}$ thickness) as shown in Fig. 5(d) but were less evident in the $\mathrm{N}$-walls (13 $\mathrm{nm}$ thickness) of the mutant (results not shown). The middle layer found as an electron-opaque layer in C-125 cells and mutant C-125-11 grown at alkaline $\mathrm{pH}$ might be an area of peptidoglycan enriched in TUP because these cells were enriched in TUP (Fig. 3).

Triple layers were not found in A-walls (18 $\mathrm{nm}$ thickness; Fig. 5e) and N-walls (16 nm thickness) of C-125-F19 or in A-walls (17 nm thickness; Fig. $5 \mathrm{f}$ ) or $\mathrm{N}$-walls (14 nm thickness) of C-125-90. The cell walls of mutants C-125F19 and C-125-90 consisted of a dense monolayer and this appeared to be little affected by changes in culture $\mathrm{pH}$. The monolayers of these cell walls seemed to lack the electron-dense outermost lamella and the electron-opaque middle lamella found in the A-walls of strains C-125 and C-125-11 (Figs 5b, d). All four strains possessed relatively thick cell walls when the grew at alkaline $\mathrm{pH}$.

\section{Density of fixed negative charges in the cell-wall matrix}

We previously describer the culture-pH-dependent alteration of the chemica: composition of cell walls of alkaliphilic strains of Extillus spp. (Aono \& Horikoshi, 1983; Aono, 1985). At the time, we were unable to interpret this alteration in terms of the negative-charge density provided by T JA and TUP because of the lack of information on the morphology of the cell walls. We supposed that the alteration might be one of the physio- 


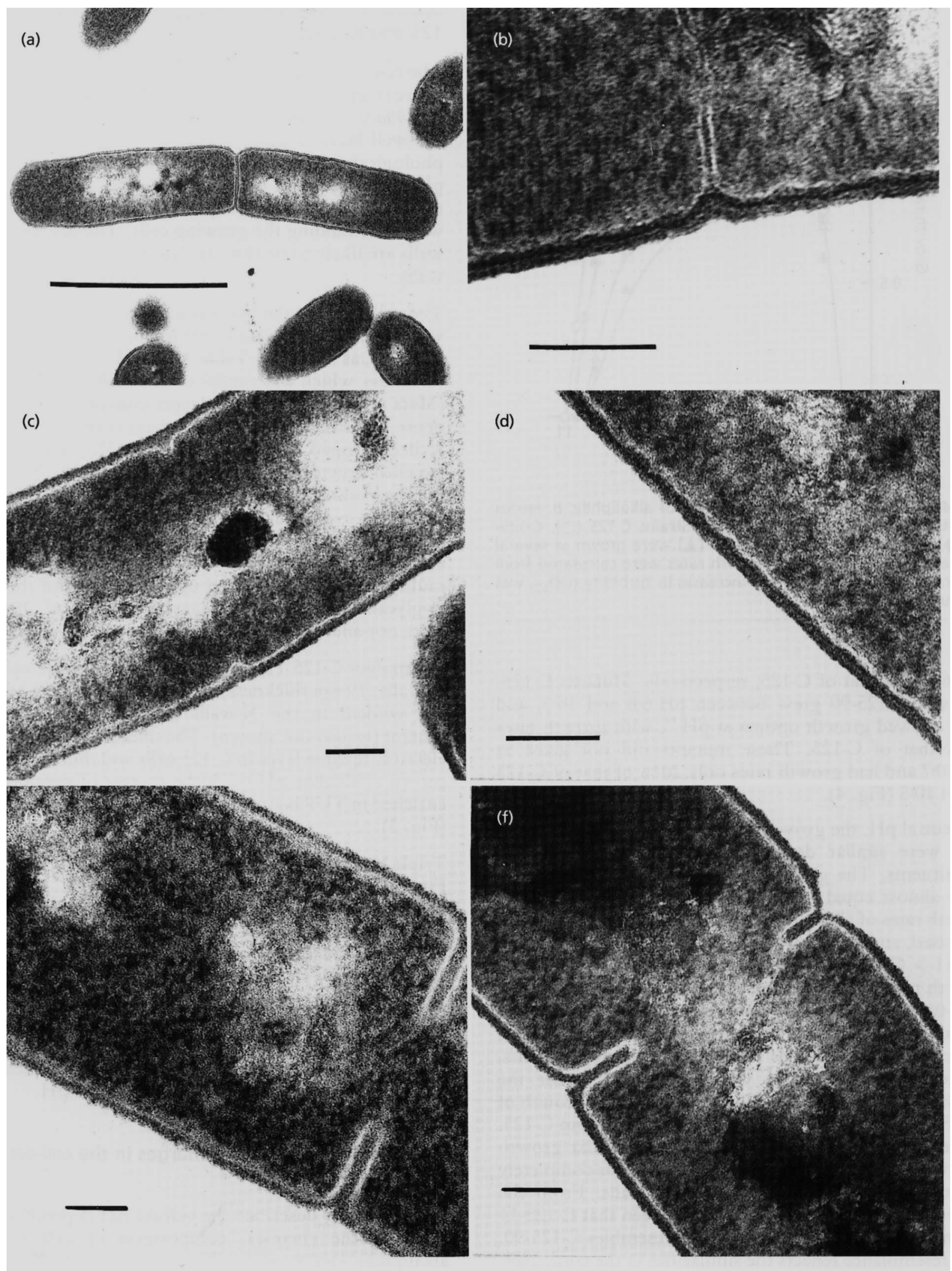

Fig. 5. Electron micrographs of cell walls of alkaliphilic $B$. lentus $C-125$ and its cell-wall-defective derivatives. Cells of $C$ 125 (a-c), C-125-11 (d), C-125-F19 (e) and C-125-90 (f) were grown at pH 7 (c) or 10 (a, b, d-f). The fixation and staining procedure for the cells in the exponential phase of growth is given in Methods. Bars, $1.0 \mu \mathrm{m}(\mathrm{a})$ or $0.1 \mu \mathrm{m}(\mathrm{b}-\mathrm{f})$. 
Table 4. Cell-wall thickness of the derivatives

Electron micrographs of the cells grown at $\mathrm{pH} 7$ or 10 were taken at magnifications of $\times 103600-221900$. Cell-wall thicknesses were measured by using several micrographs. A mean value $(\bar{x})$ and standard deviation (SD) were calculated for 20-38 measurements of the cell-wall thickness.

\begin{tabular}{|lrc|}
\hline Strain & $\begin{array}{c}\text { Culture } \\
\text { pH }\end{array}$ & $\begin{array}{c}\overline{\boldsymbol{x}} \pm \text { SD } \\
\text { (nm) }\end{array}$ \\
\hline C-125 & 10 & $21 \cdot 5 \pm 2 \cdot 2$ \\
& 7 & $18 \cdot 0 \pm 3 \cdot 1$ \\
C-125-11 & 10 & $18 \cdot 9 \pm 1 \cdot 4$ \\
& 7 & $12 \cdot 9 \pm 1 \cdot 9$ \\
C-125-F19 & 10 & $18 \cdot 4 \pm 2 \cdot 4$ \\
& 7 & $15 \cdot 8 \pm 3 \cdot 0$ \\
C-125-90 & 10 & $17 \cdot 2 \pm 1 \cdot 9$ \\
& 7 & $13 \cdot 5 \pm 1 \cdot 6$ \\
\hline
\end{tabular}

logical adaptations of the organisms to alkaline environments. In the present study there is information available to calculate charge densities for the cell walls of the wildtype and its mutants, although the observed cell walls were likely to be shrunk due to the dehydration.

The cell morphology of strain C-125 depends on the culture $\mathrm{pH}$. The unit cell is a rod of approximately $0.4 \times 1.3 \mu \mathrm{m}$ at $\mathrm{pH} 10$, whereas the cell is a short rod of approximately $0.6 \times 1.2 \mu \mathrm{m}$ at $\mathrm{pH}$. These cells have walls of 21.5 or $18.0 \mathrm{~nm}$ in thickness (Table 4). If the cell is assumed to have the shape of a simple cylinder, a volume can be calculated for the cell walls (the space external to the cytoplasmic membrane) in each type of cell. We have calculated that the volume of a cell-wall region of $\mathrm{C}-125$ grown at $\mathrm{pH} 7$ is about $4.9 \times 10^{-2}{\mu \mathrm{m}^{3}}^{3}$ and the volume of a cell grown at $\mathrm{pH} 10$ is about $3.8 \times 10^{-2} \mu \mathrm{m}^{3}$.

A cell-wall preparation $\left(2.22 \mathrm{~g}\right.$ dry wt) from $2.2 \times 10^{13}$ cells of strain C-125 grown at $\mathrm{pH} 7$ contained $0.89 \mathrm{mmol}$ uronic acids and $2.5 \mathrm{mmol} \mathrm{L}$-glutamic acid. A cell-wall preparation $\left(1.23 \mathrm{~g}\right.$ dry wt) from $1.2 \times 10^{13}$ cells grown at $\mathrm{pH} 10$ contained $1.3 \mathrm{mmol}$ uronic acids and $2.6 \mathrm{mmol} \mathrm{L}-$ glutamic acid. These results indicated that sum of the two acidic compounds was $1.5 \times 10^{-16} \mathrm{~mol}$ per cell grown at $\mathrm{pH} 7$ and $3.2 \times 10^{-16} \mathrm{~mol}$ per cell grown at $\mathrm{pH} 10$. If the acidic residues are assumed to be distributed homogeneously in the cell-wall layers, the fixed negative charge concentrations in the dehydrated cell walls can be calculated as $3.1 \times 10^{-15}$ equivalents per $\mu \mathrm{m}^{3}$ of cell wall region at $\mathrm{pH} 7$ and $8.5 \times 10^{-15}$ equivalents per $\mu \mathrm{m}^{3}$ of cell wall at $\mathrm{pH} 10$. These estimates including several assumptions might be higher than in vivo negative charge densities. However, the data are indicative of large differences in the negative charges on cell walls from the two preparations. It appears that the cell walls of C- 125 grown in an alkaline environment (about $20 \%$ thicker than the cell walls at $\mathrm{pH}$ 7) have about three times the negative charge density of that in the cell walls of C-125 grown in a neutral environment. These differences are likely to have a major influence on the flux of anions and cations through the cell-wall matrix. In particular, the high negative charge density could contribute to lower $\mathrm{pH}$ in the innermost region of the cell walls by reserving hydrogen ions generated by respiration and released from the neighbouring cytoplasmic membrane (Koch, 1986; Kemper et al., 1993).

\section{ACKNOWLEDGEMENTS}

This work was partially supported by a grant for the 'Biodesign Research Program' from RIKEN to R. Aono. The authors thank D. H. Hopcroft and R. J. Bennett of the Grasslands Research Centre for technical assistance with electron microscopy.

\section{REFERENCES}

Aono, R. (1985). Isolation and partial characterization of structural components of the walls of alkalophilic Bacillus strain C-125. J Gen Microbiol 131, 105-111.

Aono, R. (1987). Characterization of structural component of cell walls of alkalophilic strain of Bacillus sp. C-125. Biochem $J$ 245, 467-472.

Aono, R. (1989). Characterization of cell wall components of the alkalophilic Bacillus strain C-125: identification of a polymer composed of polyglutamate and polyglucuronate. $J$ Gen Microbiol 135, 265-271.

Aono, R. (1995). Assignment of facultatively alkaliphilic Bacillus sp. C-125 to Bacillus lentus group 3. Int J Syst Bacteriol 45, 582-585.

Aono, R. \& Horikoshi, K. (1983). Chemical composition of cell walls of alkalophilic strains of Bacillus. J Gen Microbiol 129, 1083-1087.

Aono, R. \& Ohtani, M. (1990). Loss of alkalophily in cell-wallcomponent-defective mutants derived from alkalophilic Bacillus C125. Biochem J 266, 933-936.

Aono, R. \& Sanada, T. (1994). Hyper-autolysis of the facultative alkaliphile Bacillus sp. C- 125 cells grown at neutral $\mathrm{pH}$ : culture-pH dependent cross-linking of the peptide moieties of the peptidoglycan. Biosci Biotechnol Biochem 58, 2015-2019.

Aono, R. \& Uramoto, M. (1986). Presence of fucosamine in teichuronic acid of the alkalophilic Bacillus strain C-125. Biochem J 233, 291-294.

Aono, R., Horikoshi, K. \& Goto, S. (1984). Composition of the peptidoglycan of alkalophilic Bacillus spp. J Bacteriol 157, 688-689.

Aono, R., Ito, M. \& Horikoshi, K. (1992). Instability of the protoplast membrane of facultative alkaliphilic Bacillus sp. $\mathrm{C}-125$ at alkaline $\mathrm{pH}$ values below the $\mathrm{pH}$ optimum for growth. Biochem $J$ 285, 99-103.

Aono, R., Ito, M. \& Horikoshi, K. (1993). Regeneration of protoplasts prepared from alkaliphilic strains of Bacillus spp. Biosci Biotechnol Biochem 57, 1597-1598.

Aono, R., Ito, M., Joblin, K. \& Horikoshi, K. (1994). Genetic recombination after cell fusion of protoplasts from the facultative alkaliphile Bacillus sp. C-125. Microbiology 140, 3085-3090.

Beutler, H. O. \& Michal, G. (1974). Glutamate, determination with glutamate dehydrogenase, diaphorase and tetrazolium salts. In Methods of Enzymatic Analysis, 2nd edn, vol. 4, pp. 1708-1713. Edited by H. U. Bergmeyer. Weinheim: Verlag Chemie.

Davidson, E. A. (1966). Analysis of sugars found in mucopolysaccharides. Methods Enzymol 8, 52-60.

Ito, M., Tabata, K. \& Aono, R. (1994). Construction of a new 
teichuronopeptide-defective derivative from alkaphilic Bacillus sp. C-125 by cell fusion. Biosci Biotechnol Biochem 58, 2275-2277.

Kemper, M. A., Urrutia, M. M., Beveridge, T. J., Koch, A. L. \& Doyle, R. J. (1993). Proton motive force may regulate cell wallassociated enzymes of Bacillus subtilis. J Bacteriol 175, 5690-5696.

Kitada, M., Hashimoto, M., Kudo, T. \& Horikoshi, K. (1994). Properties of two different $\mathrm{Na}^{+} / \mathrm{H}^{+}$antiport systems in alkaliphilic Bacillus sp. strain C-125. J Bacteriol 176, 6464-6469.

Koch, A. L. (1986). The $\mathrm{pH}$ in the neighborhood of membranes generating a protonmotive force. $J$ Theor Biol 120, 73-84.

Mera, M. U., Kemper, M., Doyle, R. \& Beveridge, T. J. (1992). The membrane-induced proton motive force influences the metal binding ability of Bacillus subtilis cell wall. Appl Environ Microbiol 58, 3837-3844.

Stepka, W. (1957). Identification of amino acids by paper chromatography. Methods Enzymol 3, 504-528.

Trevelyan, W. E., Procter, D. P. \& Harrison, J. S. (1950). Detection of sugars on paper chromatograms. Nature 166, 444-445.

Wheat, R. W. (1966). Analysis of hexosamines in bacterial polysaccharides by chromatographic procedures. Methods Enzymol 8, 60-78.

Received 3 March 1995; revised 14 July 1995; accepted 19 July 1995. 